\title{
Antibodies to Pathogenic Livestock Viruses in a Wild Vicuña (Vicugna vicugna) Population in the Argentinean Andean Altiplano
}

Gisela Marcoppido, ${ }^{1,2,5}$ Viviana Parreño, ${ }^{1,3}$ and Bibiana Viláa $2,3,4 \quad{ }^{1}$ Instituto de Virología, CICVyA, INTA
Castelar, Buenos Aires, Argentina; ${ }^{2}$ VICAM, P.O. Box 129 (6700), Luján, Buenos Aires, Argentina; ${ }^{3}$ CONICET
(Consejo Nacional de Investigaciones Científicas y Técnicas), Argentina; ${ }^{4}$ Universidad Nacional de Luján, Ruta 5 y ruta 7, Luján, Buenos Aires, Argentina; ${ }^{5}$ Corresponding author (email: gmarcoppido@ @ cnia.inta.gov.ar)

ABSTRACT: Serum samples from 128 wild vicuñas (Vicugna vicugna) were tested for antibodies $(\mathrm{Ab})$ to rotavirus $(\mathrm{RV})$, bovine parainfluenza virus 3 (BPIV-3), bovine herpesvirus-1 (BHV-1), bovine viral diarrhea virus (BVDV-1), foot-and-mouth disease virus (FMDV), bluetongue virus (BTV), equine herpesvirus-1 (EHV-1), and influenza A virus equine (EIV). Samples were collected in Cieneguillas Province of Jujuy, in northern Argentina. Feces from 44 vicuñas were also collected to investigate RV shedding. Llamas (Lama glama) and domestic cattle (Bos taurus) from the area studied also were tested for antibodies to these viruses. Antibodies against RV $(100 \%)$ and BPIV-3 (37\%) were detected in the vicuñas sampled. No RV antigen was detected in any of the fecal samples tested. One vicuña was positive for $\mathrm{Ab}$ to $\mathrm{BHV}-1$ $(0.78 \%)$ and another for BVDV-1 (0.78\%). The $\mathrm{Ab}$ prevalences detected in llamas were: $100 \%$ (16/16) for RV, 47\% (8/17) for BPIV-3, 17.6\% (3/17) for BHV-1, and 5.88\% (1/17) for BVDV1. However, domestic cattle had high antibody prevalences for RV and BPIV-3, 100\% (13/13) and $73.3 \%(11 / 15)$, respectively, but were negative for $\mathrm{Ab}$ to $\mathrm{BHV}-1$ and BVDV. No antibodies against FMDV, BTV, EHV-1, or EIV were detected in wild vicuñas or domestic species. Because no data of viral circulation on wild vicuñas are available, this report represents the first evidence of viral infection in wild vicuñas from the Argentinean Andean Puna.

Key words: Antibodies, Argentinean $\mathrm{Pu}$ na, prevalence, serology, viral disease, wild vicuñas.

There are four species of South American camelids; two are domestic, including the llama (Lama glama) and the alpaca (Lama pacos), and two are wild including the guanaco (Lama guanicoe) and the vicuña (Vicugna vicugna). South American camelids have a wide distribution along the Andes, but vicuñas are restricted to the Andean Puna (between 3,200 to 4,700 m elevation) of Perú, Bolivia, Chile, and Argentina, and they have one of the finest fibers in the world (Wheeler and Hoces, 1997). The systematic killing of vicuñas to harvest their fleece caused a severe decline in their population, almost reaching extinction in the middle of the twentieth century. After $20 \mathrm{yr}$ of effective protection laws, the number of vicuñas of some Argentinean populations has increased (Laker et al., 2006), and they are currently classified under Appendix II of the Convention on International Trade in Endangered Species (CITES), which allows the harvesting of fiber from live shorn animals. Camelids are susceptible to infectious agents that cause disease in domestic animals. Previous studies have reported serologic evidence of exposure to rotavirus (RV), bovine parainfluenza-3 virus (BPIV-3), bovine herpesvirus-1 (BHV-1), bovine viral diarrhea virus (BVDV), foot-and-mouth disease virus (FMDV), bluetongue virus (BTV), bovine enterovirus (BEV), bovine adenovirus (Badv III), influenza A virus (IAV), and equine herpesvirus-1 (EHV-1) in domestic South American camelids, most from animals without clinical presentation of disease (Fowler, 1994; Mattson and Baker, 1994; Saraiva, 2004; Cabello et al., 2006; Celedón et al., 2006; Evermann, 2006; Parreño and Marcoppido, 2006). Viral antigens were detected in domestic camelids in the presence of clinical signs of disease for BVDV, adenovirus, EHV-1, West Nile virus (Mattson and Baker, 1994; Mattson et al., 2006; Parreño and Mar- 
coppido, 2006; Foster et al., 2007), and equine arteritis virus (EAV) (Weber et al., 2006). Studies carried out on wild South American camelids under captive conditions have reported $95 \%$ antibody $(\mathrm{Ab})$ prevalence to $\mathrm{RV}$ in guanacos from the Argentinean Patagonia region and the first isolation and characterization of $\mathrm{RV}$ in guanaco crias with acute diarrhea (Parreño et al., 2001, 2004). Serologic surveys conducted in free-ranging guanacos and vicuñas did not detect $\mathrm{Ab}$ against $\mathrm{BHV}-1$, BVDV, BPIV-3, BTV, FMDV, bovine respiratory syncytial virus (BRSV), or EHV-1 (Karesh et al., 1998; Celedón et al., 2001). In domestic cattle herds from Jujuy, previous studies have reported high antibody prevalence to RV (100\%) and $\mathrm{BEV}(>90 \%)$, moderate antibody prevalence to BVDV (between $30 \%$ and $70 \%$ ), and a low antibody prevalence to $\mathrm{BHV}-1$ (between $4 \%$ and $40 \%$ ) and Badv III (9.5\%; Puntel et al., 1999). Because no data for viral circulation on wild vicuñas were available, the purpose of this study was to investigate the presence of antibodies against several livestock-affecting viruses in wild vicuña populations of the Argentinean Andean Altiplano.

We surveyed free-living vicuñas, llamas, and domestic cattle from Cieneguillas $\left(22^{\circ} 08^{\prime} \mathrm{S}, 65^{\circ} 08^{\prime} \mathrm{W}\right)$, a small town on the Province of Jujuy on the ArgentineanBolivian border of the Andean Puna, for evidence of exposure to viral agents affecting livestock. Wild vicuñas were captured under the Animal Welfare protocols (Gimpel and Bonacic, 2006), during May and November 2003 and November 2004. In total, 128 vicuñas (76 males and 52 females) were sampled and aged as crias (between $3 \mathrm{mo}$ and $1 \mathrm{yr} ; n=20$ ), juveniles (1-2 yr; $n=55)$, and adults $(>2 \mathrm{yr} ; n=53)$. Additionally, 17 llamas and 15 mixed-breed domestic cattle that grazed in the area with the vicuñas were also sampled during November 2003 and November 2004. Blood samples were obtained by venipuncture (Fowler, 1998) with 10-ml silicone-coated tube Vacutain- ers $^{\mathrm{TM}}$ (Becton Dickinson and Company), and after centrifugation, sera were separated and kept at $-20 \mathrm{C}$ until assay. Fecal samples from 44 vicuñas (20 crias and 24 adults) were collected and screened for group A RV by enzyme-linked immunosorbent assay (ELISA), using reagents and techniques previously described for RV antigen detection (Cornaglia et al.,1989). This technique was adapted for detection of $\mathrm{Ab}$ to RV in South American camelids serum samples (Parreño et al., 2001). Briefly, I-801 NCDV Cody P[1]G8 BRV reference strain was used as positive antigen, and Mock-infected MA-104 cells were used as negative control. A commercial peroxidase-labeled polyclonal goat anti-llama immunoglobin $\mathrm{G}(\mathrm{IgG})(\mathrm{H}+\mathrm{L})$ (Bethyl Laboratory Inc., Montgomery, California, USA) at 1:2,000 dilution was used as conjugate. Antibody titers were expressed as the inverse of the highest dilution with positive signal.

Serum neutralization tests (SN) for BHV-1 and BVDV-1 were carried out following standard methods (OIE, 2008), using reference strains BHV-1 Los Angeles and BVDV-1 Singer (cytopathic biotype 1a), respectively. Antibodies to BPIV-3 were detected by a hemagglutination-inhibition test (HI; Collins et al., 1996) especially adapted for South American camelid sera, using BPIV-3 reference strain ST20. Briefly, potassium periodateglycerol pretreated sera were diluted from $1 / 5$ to $1 / 320$ in " $U$ "-shape microtiter plates and mixed with an equal volume of BPIV3 containing 8 hemagglutination units (HU). After $1 \mathrm{hr}$ incubation at room temperature, two volumes of $0.25 \%$ guinea-pig erythrocytes suspension in PBS were added. Serum Ab titer was expressed as inhibitory hemagglutination units (IHU) at the highest serum dilution showing complete inhibition of the viral hemagglutination activity, multiplied by the $8 \mathrm{HU}$ of the virus used in the test. Antibodies against BTV were detected using a commercial immunodiffusion (BTID) test (Veterinary Diagnostic Tech- 
TABLE 1. Prevalence of antibodies to viral pathogens in wild vicuñas, llamas, and domestic cattle from Cieneguillas, Jujuy.

\begin{tabular}{|c|c|c|c|c|}
\hline \multirow[b]{2}{*}{ Species } & \multicolumn{4}{|c|}{ Antibody prevalence to viral pathogens ${ }^{\mathrm{a}}$} \\
\hline & $\mathrm{RV}$ & BPIV $-3^{b}$ & BHV-1 & BVDV-1 \\
\hline Wild vicuñas & $100 \%(128 / 128)$ & $37 \%(44 / 119)^{\mathrm{c}}$ & $0.78 \%(1 / 128)$ & $0.78 \%(1 / 128)$ \\
\hline Llamas & $100 \%(16 / 16)^{\mathrm{c}}$ & $47 \%(8 / 17)$ & $5.88 \%(1 / 17)$ & $17.6 \%(3 / 17)$ \\
\hline Domestic cattle & $100 \%(13 / 13)^{\mathrm{c}}$ & $73.3 \%(11 / 15)$ & $0 \%(0 / 15)$ & $0 \%(0 / 12)^{\mathrm{c}}$ \\
\hline
\end{tabular}

nology, Inc., Wheat Ridge, Colorado, USA). A blocking ELISA was used for detection of $\mathrm{Ab}$ to FMDV, using the Argentinean isolates O1 Caseros (Mattion et al., 2004). Antibodies against EHV-1 were detected by SN (OIE, 2008), using the Kentucky reference strain. For EIV, an HI test with the Argentinean isolate AR93 (Lai et al., 2001) was carried out using chicken erythrocytes.

For RV and BPIV-3, sera from naturally infected guanacos served as positive controls (Parreño et al., 2001; Marcoppido, unpubl. data). The positive controls for BHV-1 and BVDV-1 were obtained from vaccinated llamas. For FMDV, BTV, EHV-1, and EIV, sera from naturally infected domestic cattle and equines were used as positive controls, respectively.

Fisher's exact test was used to compare $\mathrm{Ab}$ titers in relation to the capture season, sex, and age of vicuñas. Differences in $\mathrm{Ab}$ titers between groups were evaluated by general analysis of variance (ANOVA) followed by Bonferroni post-ANOVA test (Statistix 8, Analitical Software, Tallahassee, Florida, USA). Significance was established at $P<0.05$.

All animals sampled had serum $\mathrm{Ab}$ against RV (Table 1). The mean Ab titers were 4,032 (range 16 to 16,384 ) in vicuñas, 362 in llamas (range 4 to 16,384 ), and 121 in domestic cattle (range 16 to 1,024). However, RV shedding could not be detected by ELISA in any of the wild vicuñas sampled, including the 20 crias.
Comparison of $\mathrm{Ab}$ titers in vicuñas according to age revealed statistically significant differences (Table 2). Analyzing the total wild vicuñas sampled, the highest $\mathrm{Ab}$ titer to RV was detected in the juvenile vicuñas, while the lowest was detected in the total crias $(P=0.0156)$. When comparing the mean $\mathrm{Ab}$ titers to $\mathrm{RV}$ between captures in 2003, the crias showed lower titers than juvenile and adult animals in November $(P=0.0182)$, while the crias captured in May had very high titers, similar to those of the older categories (Table 2). No statistically significant difference in Ab titers to RV was observed between sexes.

Average antibody prevalence to BPIV-3 was $37 \%$ for vicuñas, $47 \%$ for llamas, and $73.3 \%$ for domestic cattle (Table 1). The $\mathrm{Ab}$ titers for BPIV-3 ranged from 160 to 1,280 for vicuñas, 80 to 2,560 for llamas, and 80 to 320 for domestic cattle. The $\mathrm{Ab}$ prevalence to BPIV-3 recorded in vicuñas during November 2003 was significantly higher than that recorded in November 2004 (Table 2). No significant differences were observed between the age classes of vicuñas, while a significantly higher antibody prevalence to BPIV-3 was detected in females $(50 \% ; 23 / 46)$ than in males $(28.76 \% ; 21 / 73)) \quad(P=0.0313$; data not shown).

Only one juvenile male vicuña and a male llama were seropositive to BHV-1 (SN Ab titer of 1.8 in both), while an adult male vicuña and three llamas (two males 
TABLE 2. Geometric mean antibody (Ab) titers and antibody prevalence for rotavirus (RV) and bovine parainfluenza virus 3 (BPIV-3) in relation to the date of capture and age of the vicuñas sampled.

\begin{tabular}{|c|c|c|c|c|c|c|}
\hline \multirow[b]{3}{*}{ Capture } & \multirow[b]{3}{*}{ Age } & \multirow[b]{3}{*}{$n$} & \multicolumn{4}{|c|}{ Viral pathogens } \\
\hline & & & \multicolumn{2}{|c|}{$\mathrm{RV}$} & \multicolumn{2}{|c|}{ BPIV $-3^{a}$} \\
\hline & & & GM Ab titer ${ }^{b}$ & $\mathrm{Ab}$ prevalence ${ }^{\mathrm{C}}$ & GM Ab titer $^{\mathrm{b}}$ & $\mathrm{Ab}$ prevalence \\
\hline \multirow{4}{*}{$\begin{array}{r}\text { May } 2003 \\
\quad(n=28)\end{array}$} & Adult & 13 & $1,745^{\mathrm{B}}$ & \multirow[t]{4}{*}{$100 \%$} & 89 & $23 \%(3 / 13)$ \\
\hline & Juvenile & 11 & $6,781^{\mathrm{A}}$ & & 141 & $55 \%(6 / 11)$ \\
\hline & Crias & 4 & $5,793^{\mathrm{AB}}$ & & 80 & $25 \%(1 / 4)$ \\
\hline & & & $P=0.0250$ & & $P=0.2359$ & $35.71 \%{ }^{\mathrm{AB}}$ \\
\hline \multirow{4}{*}{$\begin{array}{r}\text { Nov } 2003 \\
\quad(n=50)\end{array}$} & Adult & 21 & $897^{\mathrm{AB}}$ & \multirow[t]{4}{*}{$100 \%$} & 120 & $53 \%(10 / 19)$ \\
\hline & Juvenile & 17 & $1,670^{\mathrm{A}}$ & & 147 & $63 \%(10 / 16)$ \\
\hline & Crias & 12 & $323^{\mathrm{B}}$ & & 103 & $36 \%(4 / 11)$ \\
\hline & & & $P=0.0182$ & & $P=0.5769$ & $52.17 \%{ }^{\mathrm{A}}$ \\
\hline \multirow{4}{*}{$\begin{array}{r}\text { Nov } 2004 \\
\quad(n=50)\end{array}$} & Adult & 19 & 5,098 & \multirow[t]{4}{*}{$100 \%$} & 94 & $35 \%(6 / 17)$ \\
\hline & Juvenile & 27 & 1,996 & & 69 & $17 \%(4 / 24)$ \\
\hline & Crias & 4 & 1,024 & & 57 & $0 \%(0 / 4)$ \\
\hline & & & $P=0.0556$ & & $P=0.2095$ & $22.2 \%^{\mathrm{B}}$ \\
\hline \multirow{4}{*}{$\begin{array}{r}\text { Total wild } \\
\text { vicuñas }\end{array}$} & Adult & 53 & $1,969^{\mathrm{AB}}$ & \multirow[t]{4}{*}{$100 \%$} & 102 & $39 \%(19 / 49)$ \\
\hline & Juvenile & 55 & $2,413^{\mathrm{A}}$ & & 102 & $39 \%(20 / 51)$ \\
\hline & Crias & 20 & $724^{\mathrm{B}}$ & & 86 & $26 \%(5 / 19)$ \\
\hline & & & $P=0.0156$ & & $P=0.6923$ & \\
\hline
\end{tabular}

${ }^{a}$ Only the serum samples with Ab titers $>80$ IHU were considered positive.

${ }^{\mathrm{b}}$ Different letters $(\mathrm{A}, \mathrm{B}$, and $\mathrm{AB})$ in the same column indicate significant differences in mean titers between animals of different categories within a capture (one-way ANOVA, Bonferroni $P<0.05$ ).

${ }^{\mathrm{c}}$ Total of seropositive animals/total of animals tested (\% positive).

and one female) had detectable antibodies against BVDV-1 (Table 1). Mean Ab titers of positive animals of each species are depicted in Figure 1. None of the sero- positive animals sampled had clinical signs of diseases, and all were in good physical condition. No Ab to BHV-1 or BVDV-1 was detected in the domestic cattle

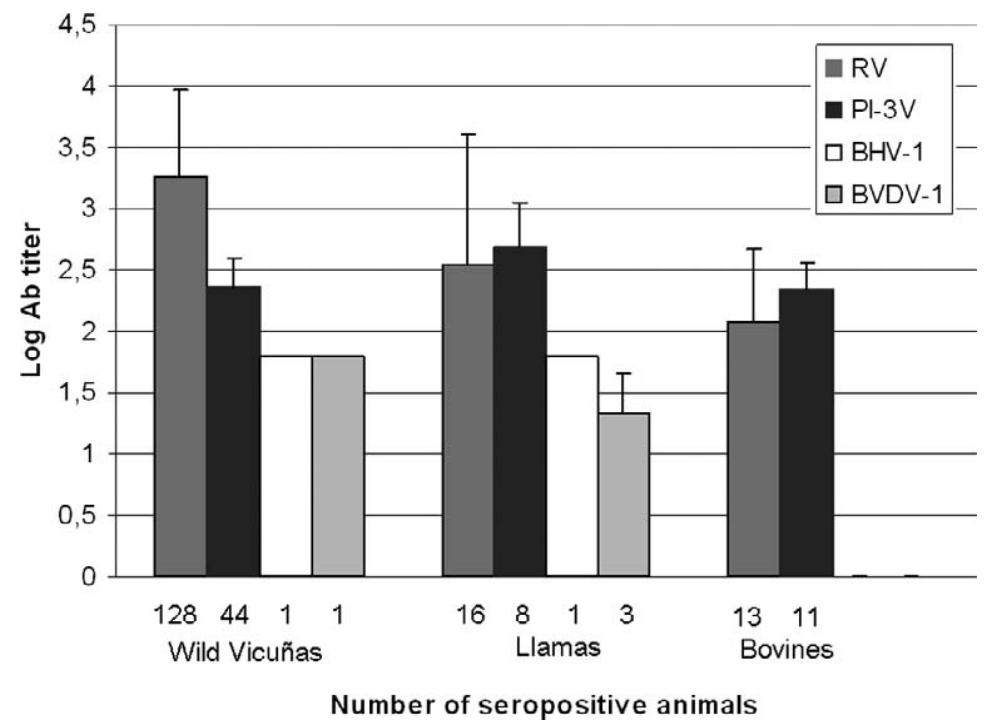

Figure 1. Average antibody titers of seropositive vicuñas, llamas, and domestic cattle for each virus studied. Error bars represent standard deviation. 
sampled. No animals seropositive for FMDV, BTV, EHV-1, and EIV were detected in any species.

Using indirect evidence, we have demonstrated the asymptomatic circulation of RV and BPIV-3 in wild vicuñas, llamas, and domestic cattle from the Argentinean Puna. Similar prevalences of RV Ab have been found in a survey carried out in llamas from different provinces of Argentina, including Jujuy (Puntel et al., 1999). The prevalence for BPIV-3 detected in this study is consistent with the rates previously reported (Mattson and Baker, 1994; Cabello et al., 2006; Parreño and Marcoppido, 2006). These results highlight the importance of avoiding captive breeding programs in vicuñas due to the high possibility of a massive outbreak of these indigenous diseases. The stressful stimuli imposed by captivity have detrimental effects, including a decrease in the immune competence of animals, which affects the survival of the individuals when faced with pathogens (Texeira et al., 2007).

Antibody prevalences for $\mathrm{BHV}-1$ and BVDV-1 in the vicunas and llamas studied were very low. This finding agrees with the low prevalence reported in other studies in llamas and wild South American camelids from Argentina, Perú, and the USA (Parreño and Marcoppido, 2006). In this report, antibodies against FMDV, BTV, EHV-1, and EIV were not detected in wild vicuñas or domestic animals. Similar results have been reported in free-ranging guanacos (Karesh et al., 1998). Our results agree with other studies that did not detect seropositive llamas to FMDV in Argentina (Puntel et al., 1999) and support the hypothesis that camelids play a minor role in the transmission of the virus (Fondevilá et al., 1995; Saraiva, 2004; Wernery and Kaaden, 2004). The lack of detection of $\mathrm{Ab}$ to BTVs in the animals sampled agrees with previous reports in domestic and wild South American camelids and domestic cattle from the northern end of Argentina (Puntel et al., 1999).
Because BTVs are transmitted by Culicoides spp., the absence of detectable $\mathrm{Ab}$ in the animals tested could be due to the absence of competent vectors in the Argentinean Puna around the time of sampling (Lager, 2004). No Ab against EHV-1 or EIV was found in the animals sampled. Despite the lack of published data on diseases of equids in the Argentinean Puna, the cooperating farmers in this study did not allow the sampling of donkeys.

Although virus isolation was not performed in this study, serologic results allow the conclusion that all species sampled had been exposed to RV and BPIV-3. In addition, of the animals sampled, only wild and domestic South American camelids had been in contact with a viral agent antigenically related to BHV-1 and BVDV-1. The serologic tests used in this study were those of standards application for domestic cattle (OIE, 2008), but they have not been validated for camelids, and thus conclusions should be interpreted with caution. Because of the small sample sizes of llamas and domestic cattle and the low antibody prevalence recorded in this study, no conclusions concerning the risk of interspecies transmission could be drawn. A larger survey over longer periods of time is needed to better elucidate potential trends or relationship.

This study suggests that populations of free-ranging vicuñas from the Argentine Altiplano can be relatively disease-free but susceptible to common livestock disease. The present study represents the first survey for viral agents in wild vicuñas in Argentina and demonstrates the need for additional work in order to better understand the dynamics of viral infections in wild vicuñas and the potential role of these species in the epidemiology of livestock diseases. Knowledge about infectious agents affecting South American camelids is crucial at the moment of initiating appropriate systems for sustainable management of domestic llamas and 
conservation of populations of wild vicuñas.

The authors acknowledge the MACS Team: Y. Arzamendia, A. Wawrzyk, M. Borgnia H. Yacobaccio, J. Baldo, H. Lamas, M. Morales, and C. Bonacic; S. Romero from INTA Abra Pampa; research groups from the Virology Institute of INTA Castelar: D. Rodríguez, S. Duro, N. D’Amico, D. Franco; M. Barrandeguy, A. Visani, L. Becerra, K. Trono, M. Lomónaco, N. Pacienza, L. Snaiderman, M. Trotta, and F. Fernandez; and Los Pioneros Association and the community of Cieneguillas, Jujuy. The Argentinean National Research Council (CONICET) and MACS project (INCO II Program of the European Commission, DG Research,

8 ICA4-2000-10229) supported this project.

\section{LITERATURE CITED}

Cabello, K., R. Quispe Ch, and H. Rivera G. 2006 Frecuencia de los virus parainfluenza-3, respiratorio sincitial y diarrea viral bovina en un rebaño mixto de una comunidad de Cusco. Revista de Investigaciones Veterinarias de Perú 17.

Celedón, M. O., J. Osorio, and J. Pizarro. 2006 Aislamiento e identificación de pestivirus obtenidos de alpacas (Lama pacos) y llamas (Lama glama) de la Región Metropolitana, Chile. Archivos de Medicina Veterinaria 38: 247-252.

- - A. Sandoval, J. Droguett, R. Calfio, L. Ascencio, J. Pizarro, and B. Navarro. 2001. Pestisa de anticuerpos seroneutralizantes para pestivirus y herpesvirus en ovinos, caprinos y camélidos sudamericanos de Chile. Archivos de Medicina Veterinaria 33: 165-172.

Collins, P. B., R. M. Hanock, and K. McIntosh. 1996. Parainfluenza viruses. In Fields Virology, 3rd Edition, B. N. Fields, D. M. Knipe, and P. M. Howley (eds.). Lippincott Williams \& Wilkins, Philadelphia, Pennsylvania, 3144 pp.

Cornaglia, E. M., M. Barrandeguy, N. Fijtman, and A. Schudel. 1989. Enzyme-linked immunosorbent assay, immunofluorescence test and electrophoretic analysis of rotaviral RNA in the diagnosis and characterization of bovine rotavirus. Revista Latino Americana de Microbiología 31: 59-62.

Evermann, J. F. 2006. Pestiviral infection of llamas and alpacas. Small Ruminant Research 61: 201206

Fondevilá, N., F. J. Marcovecchio, J. B. Blanco
Viera, V. K. O’Donnel, B. J. Carrillo, A. A Schudel, M. David, A. Torres, and C. A. Mebus. 1995. Susceptibility of llamas (Lama glama) to infection with foot-and-mouth-disease virus. Zentralbl Veterinarmed B. Dec. 42: 595.

Foster, A. P., M. G. Houlihan, J. P. Holmes, E. J. Watt, R. J. Higgins, J. Errington, G. Ibata, and P. R. WAKELEy. 2007. Bovine viral diarrhea virus infection of alpacas (Vicugna pacos) in the UK. The Veterinary Record 161: 94-99.

Fowler, M. 1998. Medicine and surgery of South American camelids. 2nd Edition. Iowa State University Press, Iowa, USA, 391 pp.

Gimpel, R. J., and C. Bonacic. 2006. Manejo sostenible de la vicuña bajo estándares de bienestar animal. In Investigación, conservación y manejo de las vicuñas, B. Vilá (ed.). Proyecto MACS-Argentina, Buenos Aires, Argentina, 208 pp.

Karesh, W., M. M. Uhart, E. S. Dierenfeld, W. E. Braselton, A. Torres, C. House, H. Puche, and R. A. Cоок. 1998. Health evaluation of freeranging guanaco (Lama guanicoe). Journal of Zoo and Wildlife Medicine 29: 134-141.

Lager, I. 2004. Bluetongue virus in South America: Overview of viruses, vectors, surveillance and unique features. Veterinaria Italiana 40: 89-93.

Lai, A. C. K., T. M. Chambers, R. E. Holland, P. S. Morley, D. M. Haines, H. G. G. Townsend, and M. Barrandeguy. 2001. Diverged evolution of recent equine-2 influenza (H3N8) viruses in the Western Hemisphere. Archives of Virology 146: 1063-1074.

Laker, J., J. Baldo, Y. Arzamendia, and H. D. Yacobaccio. 2006. La vicuñas de los Andes. In Investigación, conservación y manejo de las vicuñas, B. Vilá (ed.). Proyecto MACS-Argentina, Buenos Aires, Argentina, 208 pp.

Mattion, N., G. Konig, C. Seki, E. Smitsaart, E. Maradei, B. Robiolo, S. Duffy, E. Leon, M Piccone, A. Sadir, R. Bottini, B. Cosentino, A Falczuk, R. Maresca, O. Periolo, R. Bellin zoni, A. Espinoza, J. L. Torre, and E. L. Palma. 2004. Reintroduction of foot-and-mouth disease in Argentina: Characterization of the isolates and development of tools for the control and eradication of the disease. Vaccine 22: 41494162.

Mattson, D. E., and R. J. Baker. 1994. Viral diseases. Veterinary Clinics of North America 10: 345-351.

- J. E. Catania, S. R. Imbur, K. M. Wellejus, AND R. B. Bell. 2006. Persistent infection with bovine viral diarrhea virus in an alpaca. Journal of the American Veterinary Medical Association 228: 1762-1765.

OIE. 2008. Manual of diagnostic tests and vaccines for terrestrial animals, Vol. II. 6th Edition. World Organization for Animal Health, Paris, 14 France. 
Parreño, V., and G. Marcoppido. 2006. Estudio de la sanidad en camélidos: Avances a partir de la obtención de muestras de camélidos silvestres. In Investigación, conservación y manejo de las vicuñas, B. Vilá (ed.). Proyecto MACS-Argentina, Buenos Aires, Argentina, 208 pp.

K. BoK, F. Fernandez, and J. Gomez. 2004. Molecular characterization of the first isolation of rotavirus in guanacos (Lama guanicoe). Archives of Virology 149: 2465-2467. V. Constantini, S. Cheetham, J. Blanco Viera, L. J. Saif, F. Fernandez, L. LEONi, AND A. Schudel. 2001. First isolation of rotavirus associated with neonatal diarrhea in guanacos (Lama guanicoe) in the Argentinean Patagonia region. Journal of Veterinary Medicine B 48: 713-720.

Puntel, M., N. A. Fondevilá, J. Blanco Viera, V. K. O’Donnell, J. F. Marcovecchio, B. J. Carrillo, AND A. A. SChudel. 1999. Serological survey of viral antibodies in llamas (Lama glama) in Argentina. Journal of Veterinary Medicine B 46: $157-161$.
Saraiva, V. 2004. Foot-and-mouth disease in the Americas: Epidemiology and ecologic changes affecting distribution. Annals of the New York Academy of Science 1026: 73-78.

Texeira, C. P., C. S. De Azevedo, M. Mendl, C. F. Cipreste, and R. J. Young. 2007. Revisiting translocation and reintroduction programmes: The importance of considering stress. Animal Behaviour 73: 1-13.

Weber, H., K. Beckmann, and L. Haas. 2006. Case report: Equine arteritis virus (EAV) as the cause of abortion in alpacas? Deutsche Tierärztliche Wochenschrift 113: 162-163.

Wernery, U., and O. R. Kaaden. 2004. Foot-andmouth disease in camelids: A review. Veterinary Journal 168: 134-142.

Wheeler, J., and D. Hoces. 1997. Community participation, sustainable use, and vicuña conservation in Perú. Mountain Research and Development 17: 283-287.

Submitted for publication 3 April 2008. 
Authors Queries

Journal: Journal of Wildlife Diseases

Paper: jwdi-46-02-33

Title: Antibodies to Pathogenic Livestock Viruses in a Wild Vicuña ?(Vicugna vicugna) Population in the Argentinean Andean Altiplano

Dear Author

During the preparation of your manuscript for publication, the questions listed below have arisen. Please attend to these matters and return this form with your proof. Many thanks for your assistance

\begin{tabular}{|l|l|l|}
\hline $\begin{array}{l}\text { Query } \\
\text { Reference }\end{array}$ & Query & Remarks \\
\hline 1 & $\begin{array}{l}\text { Author: This article has } \\
\text { been lightly edited for } \\
\text { grammar, style, and us- } \\
\text { age. Please compare it } \\
\text { with your original docu- } \\
\text { ment and make correc- } \\
\text { tions on these pages. }\end{array}$ & $\begin{array}{l}\text { Please limit your correc- } \\
\text { tions to substantive } \\
\text { changes that affect mean- } \\
\text { ing. If no change is re- } \\
\text { quired in response to a } \\
\text { question, please write "OK } \\
\text { as set" in the margin. } \\
\text { Copy editor }\end{array}$ \\
\hline 2 & $\begin{array}{l}\text { Author: Please spell out } \\
\text { ClCVyA, INTA in first affil- } \\
\text { iation and VICAM in sec- } \\
\text { ond affiliation and provide } \\
\text { full addresses (including } \\
\text { city and postal codes) for } \\
\text { all affiliations. Provide de- } \\
\text { partment for fourth affilia- } \\
\text { tion? Copy editor }\end{array}$ & \\
\hline
\end{tabular}




\begin{tabular}{|c|c|}
\hline 3 & $\begin{array}{l}\text { Author: In the first para- } \\
\text { graph of the text, you cite } \\
\text { Fowler (1994). This is list- } \\
\text { ed as } 1998 \text { in the literature } \\
\text { cited list. Which date is } \\
\text { correct? Also, you cite } \\
\text { Mattson (1994). This has } \\
\text { been edited to Mattson } \\
\text { and Baker (1994) to match } \\
\text { the literature cited list. } \\
\text { Copy editor }\end{array}$ \\
\hline 4 & $\begin{array}{l}\text { Author: Please provide } \\
\text { city, state/province, and } \\
\text { country for Becton Dickin- } \\
\text { son and Co. in methods } \\
\text { paragraph. Copy editor }\end{array}$ \\
\hline 5 & $\begin{array}{l}\text { Author: Please spell out } \\
\text { PBS at first use in third } \\
\text { paragraph. Copy editor }\end{array}$ \\
\hline 6 & $\begin{array}{l}\text { Author: Please define GM } \\
\text { in title or footnote for Table } \\
\text { 2. Copy editor }\end{array}$ \\
\hline 7 & $\begin{array}{l}\text { Author: Please verify titer } \\
1.8 \text { in first sentence of } \\
\text { eighth paragraph. It } \\
\text { seems like an odd titer: } \\
\text { should it be } 8 \text { ? Copy editor }\end{array}$ \\
\hline 8 & $\begin{array}{l}\text { Author: Please spell out } \\
\text { MACS at first use in ac- } \\
\text { knowledgments para- } \\
\text { graph. Copy editor }\end{array}$ \\
\hline 9 & $\begin{array}{l}\text { Author: Please provide } \\
\text { page range and clarify first } \\
\text { vs. surname initials for } \\
\text { Cabello et al. (2006) refer- } \\
\text { ence. Copy editor }\end{array}$ \\
\hline
\end{tabular}




\begin{tabular}{|l|l|l|}
\hline 10 & $\begin{array}{l}\text { Author: Please spell out } \\
\text { journal title in Fondevilá et } \\
\text { al. (1995) reference. Copy } \\
\text { editor }\end{array}$ & \\
\hline 11 & $\begin{array}{l}\text { Author: Please provide } \\
\text { city of publication for Fowl- } \\
\text { er (1998) reference. Copy } \\
\text { editor }\end{array}$ & \\
\hline 12 & $\begin{array}{l}\text { Author: Please verify cor- } \\
\text { rect initials for Gimpel in } \\
\text { Gimpel and Bonacic } \\
\text { (2006) reference. Copy } \\
\text { editor }\end{array}$ & \\
\hline 13 & $\begin{array}{l}\text { Author: Please verify se- } \\
\text { ries/journal title for Matt- } \\
\text { son and Baker (1994) ref- } \\
\text { erence. Copy editor }\end{array}$ & \\
\hline 14 & $\begin{array}{l}\text { Author: Please spell out } \\
\text { OlE in parentheses in OlE } \\
\text { (2008) reference. Copy } \\
\text { editor }\end{array}$ & \\
\hline
\end{tabular}

